(C) 2022, The Authors. Published by Elsevier Inc. and Fass Inc. on behalf of the American Dairy Science Association ${ }^{\circledR}$. This is an open access article under the CC BY license (http://creativecommons.org/licenses/by/4.0/).

\title{
High-digestible silages allow low concentrate supply without affecting milk production or methane emissions
}

\author{
C. Álvarez, ${ }^{1,2 *} \oplus$ N. I. Nielsen, ${ }^{3} \oplus$ M. R. Weisbjerg, ${ }^{4}{ }^{\oplus}$ H. Volden, ${ }^{1,2}{ }^{\oplus}$ M. Eknæs, ${ }^{1} \oplus$ and E. Prestløkken ${ }^{1} \oplus$ \\ ${ }^{1}$ Department of Animal and Aquaculture Sciences, Norwegian University of Life Sciences (NMBU), 1432 Ås, Norway \\ ${ }^{2}$ Tine SA, 1430 Ås, Norway \\ ${ }^{3}$ SEGES, Danish Agriculture \& Food Council, 8200 Aarhus, Denmark \\ ${ }^{4}$ Department of Animal Science, AU Foulum, Aarhus University, 8830 Tjele, Denmark
}

\begin{abstract}
In this study, we tested a response function comprising responses in milk to changes in organic matter digestibility of silages and concentrate supply. We studied the effect of changes in silage digestibility and concentrate supply on milk yield, feed intake, body weight, and methane production using 60 Norwegian Red cows. The experiment was a complete randomized block design comprising 3 periods. The pre-experimental period lasted $20 \mathrm{~d}$ and all the cows were fed a common silage for ad libitum intake and concentrate according to yield. Next, response period 1 lasted $17 \mathrm{~d}$ and the cows were divided into 2 treatments, where a low-digestible silage (LDS) was fed to half of the cows, and the other half were fed a high-digestible silage (HDS). Both groups were fed silage for ad libitum silage intake. Concentrate was optimized according to the yield and type of silage offered. In this period, the effect of silage was evaluated using a mixed model, including the results from pre-experimental period, with parity as a covariate and animal as a random effect. In response period 2, which lasted $20 \mathrm{~d}$, the concentrate level was evaluated by dividing the silage digestibility treatments further into 3 subgroups. Concentrate was increased by $2 \mathrm{~kg}$ of dry matter $(\mathrm{DM})$ per day, decreased by $2 \mathrm{~kg}$ of DM/d, or remained unchanged. In response period 1, silage treatments were optimized to obtain similar yields and resulted in a lower concentrate offer to HDS treatment. However, the HDS treatment showed a $3.0 \mathrm{~kg}$ of $\mathrm{DM} / \mathrm{d}$ higher total feed intake due to a higher than expected silage intake. This resulted in $3.5 \mathrm{~kg}$ higher energy-corrected milk (ECM). Methane emissions were similar between silage treatments, but HDS showed lower methane per kilogram of DM due to its higher intake. The effect of concentrate supply level and interaction with silage digestibility was evaluated using
\end{abstract}

Received October 25, 2021.

Accepted December 18, 2021.

*Corresponding author: clementina.alvarez@tine.no mixed models, including the results for response period 1 , with parity as a covariate and animal as a random effect. The reduction in concentrate offer by $2 \mathrm{~kg} / \mathrm{d}$ in response period 2 was compensated for by increased $1.3 \mathrm{~kg}$ of $\mathrm{DM} / \mathrm{d}$ of silage intake for HDS, resulting in similar intake $(22.1 \mathrm{~kg}$ of DM/d and $21.7 \mathrm{~kg}$ of DM/d without and with concentrate reduction, respectively) and ECM yields (29.4 and $29 \mathrm{~kg}$ of ECM without and with concentrate reduction, respectively). However, concentrate offer reduction could not be compensated for by increased silage intake for LDS and resulted in lower milk yields (27.5 kg of ECM). Increased concentrate showed a higher marginal ECM response ( $\mathrm{kg}$ of ECM per $\mathrm{kg}$ of additional concentrate intake) for LDS (1.8 vs. $3.3 \mathrm{~kg}$ of ECM for HDS and LDS, respectively). Thus, the drop in milk yields could be compensated for by increased concentrate offers if LDS are fed. Total methane production increased with increased concentrate intake, regardless of silage digestibility. Methane emissions per unit of milk were affected by total DM intake rather than by changes in silage digestibility and concentrate level. The results of this study are based on short-term periods and could show differences if study periods were longer; the results should be interpreted accordingly.

Key words: dairy cow, milk response, methane, silage maturity, meta-analysis

\section{INTRODUCTION}

The importance of forage in ruminant nutrition has been widely discussed and accepted for several reasons. Ruminants' unique characteristics of digesting fiber, a growing human population that increases competition for cropland, and higher prices of concentrates are the most cited. Silage making is a widely used conservation strategy for forage because it ensures the possibility of preserving feed for cows (Bernardes et al., 2018) with minor energy losses compared with drying (Mahanna and Chase, 2003). However, as silage digestibility varies greatly and depends on several factors, high-producing 
dairy cows are often fed high levels of concentrates to secure sufficient energy and nutrient intake to meet their requirements (Abrahamse et al., 2008). Despite this, numerous studies have shown the advantages of high-digestible silages on milk yield (Randby et al., 2012; Alstrup et al., 2014; Weisbjerg and Johansen, 2017). Álvarez et al. (2020) developed a response function from a meta-analysis study, showing a curvilinear response to increase concentrate intake, a positive linear response to silage digestibility, and an interaction between these 2. This response function showed that high-digestible silages can induce high milk yields with lower concentrate levels than low-digestible silages. At low levels of concentrate, higher milk yields were achieved with increased silage digestibility. As concentrate intake levels increase, ECM differences between silages disappear due to a lower ECM marginal response with high-digestible silages. This meta-analysis found no differences in substitution rates (SR) between silages, but other studies showed higher SR as silage digestibility increased (Thomas, 1987; Faverdin et al., 1991). In addition, several studies have shown the effect of grass maturity (Moe and Tyrrell, 1979; Johnson and Johnson, 1995; Brask et al., 2013) and concentrate level (Ferris et al., 1999; Aguerre et al., 2011; Jiao et al., 2014) on methane emissions, although these effects were studied separately. Therefore, the effect of silage digestibility and concentrate level on methane emissions requires a combined evaluation.

The objective of this study was to test the meta-analysis of Álvarez et al. (2020) by challenging cows with different silage digestibility and evaluating the interaction between silage digestibility and concentrate level on cow responses. Further, the aim was to evaluate these scenarios from a climate perspective, measuring methane emissions for different silage digestibility and concentrate levels. Based on described response function, we hypothesize that lower intake levels of concentrate are needed to maintain high milk yields by increasing silage digestibility. Moreover, higher responses of milk with increased concentrate levels will be achieved with low-digestible silages. From an environmental perspective, we hypothesize that high-digestible silages with low concentrate levels will produce less methane than low-digestible silages with higher concentrate levels.

\section{MATERIALS AND METHODS}

\section{Preparation of Grass Silages}

Silage preparation aimed to obtain silages with different organic matter digestibility (OMD). For this, 2 spaced harvest dates were performed: early harvest on May 28, 2019, and late harvest on June 18, 2019. Harvests at both dates were performed from 3 fields at the Norwegian University of Life Sciences in Ås, Norway $\left(59^{\circ} \mathrm{N}, 10^{\circ} \mathrm{E}\right)$. Based on seed weight, all fields consisted of a mix of $50 \%$ timothy (Phleum pratense), $25 \%$ meadow fescue (Festuca pratensis), $15 \%$ meadow grass (Poa pratensis), and 10\% white clover (Trifolium repens). Spring fertilization of all fields was performed on April 9 and consisted of $120 \mathrm{~kg} / \mathrm{ha}$ nitrogen (88 $\mathrm{kg}$ as mineral fertilizer and $32 \mathrm{~kg}$ as manure), $12 \mathrm{~kg} /$ ha phosphorus, and $40 \mathrm{~kg} /$ ha potassium. After cutting, grass silage was wilted for 6 to $24 \mathrm{~h}$, aiming for a DM content of 25 to $30 \%$. The grass was ensiled in round bales using $5.1 \mathrm{~L} / \mathrm{t}$ of fresh matter of a formic acidbased additive (GrasAAT Plus) and 8 layers of plastic film. Table 1 shows the DM content, chemical composition, and fermentation quality of the resulting grass silages. Samples were taken after opening the silages for feeding.

\section{Diets and Experimental Design}

The experiment was conducted at the Animal Production Experimental Center at the Norwegian University of Life Sciences, following the laws and regulations controlling experiments on live animals in Norway under the surveillance of the Norwegian Animal Research Authority.

The experiment was conducted from February 28 to April 25, 2020, and consisted of 3 periods on which the dietary treatments depended. From February 28 to March 18 (20 d duration), the pre-experimental period (PreP), 60 cows were fed a common silage for ad libitum intake, consisting of a mix of $50 \%$ low-digestible silage from the late harvest (LDS) and 50\% highdigestible silage from the early harvest (HDS; fresh weight basis). Silage mixing for offering consisted of 6 round bales, 3 from the LDS and 3 from the HDS. Within silage digestibility, one bale came from each of the 3 fields included in the study. The mixing duration was approximately $20 \mathrm{~min}$ using Siloking Duo 1814 (Kverneland) and was performed 3 times per week. Concentrate offer was determined individually for cows according to milk yield, DIM, and BW recorded over a 7-d period before initiating PreP. These optimizations were performed using the NorFor Feed Ration Optimizer (Volden, 2011b). In response period 1 (RP1), from March 19 to April 4, 2020 (17 d duration), cows were blocked by parity and were randomly allocated into 2 groups - 30 of the cows were fed HDS, and the other 30 cows were fed LDS. Silage was fed for ad libitum intake by ensuring a residue of 5 to $10 \%$ of the offer. Mixing of silage for feeding included mixing 3 
Table 1. Chemical composition of experimental silages and concentrate supplement used in the study

\begin{tabular}{|c|c|c|c|c|c|}
\hline \multirow[b]{2}{*}{ Item $^{1}$} & \multicolumn{2}{|c|}{ Silage $^{2}$} & \multirow[b]{2}{*}{ SEM } & \multirow[b]{2}{*}{$P$-value } & \multirow[b]{2}{*}{ Concentrate $^{3}$} \\
\hline & HDS & LDS & & & \\
\hline $\mathrm{DM}(\mathrm{g} / \mathrm{kg})$ & 254 & 237 & 0.404 & 0.02 & 861 \\
\hline $\operatorname{OMD}(\%)$ & 78.8 & 67.6 & 2.22 & $<0.001$ & \\
\hline \multicolumn{6}{|l|}{$\mathrm{g} / \mathrm{kg}$ of $\mathrm{DM}$} \\
\hline Ash & 83.8 & 80.4 & 1.04 & 0.11 & 73.6 \\
\hline $\mathrm{CP}$ & 215 & 144 & 13.4 & $<0.001$ & 198 \\
\hline $\mathrm{sCP}$ & 163 & 99.7 & 12.1 & $<0.001$ & 41.0 \\
\hline CFat & 33.1 & 26.8 & 1.34 & 0.006 & 33.6 \\
\hline $\mathrm{NDF}$ & 468 & 597 & 24.6 & $<0.001$ & 180 \\
\hline $\mathrm{ADF}$ & 274 & 349 & 14.4 & $<0.001$ & 74.7 \\
\hline ADL & 18.4 & 30.2 & 2.25 & $<0.001$ & 8.40 \\
\hline Starch & 22.5 & 12.7 & 0.192 & $<0.001$ & 358 \\
\hline WSC & 42.2 & 23.0 & 0.383 & $<0.001$ & 63.1 \\
\hline $\mathrm{pH}$ & 4.50 & 4.25 & 0.0591 & 0.02 & \\
\hline Lactic acid & 38.8 & 50.2 & 2.81 & 0.02 & \\
\hline Acetic acid & 7.00 & 7.75 & 0.183 & 0.02 & \\
\hline Propionic acid & 1.38 & 1.53 & 0.0926 & 0.46 & \\
\hline Butyric acid & 0.40 & 0.40 & 0.00 & 0.36 & \\
\hline Formic acid & 9.00 & 7.00 & 0.463 & 0.01 & \\
\hline Ethanol & 5.78 & 5.40 & 0.178 & 0.33 & \\
\hline Ammonium-N ( $\mathrm{g} / \mathrm{kg}$ of $\mathrm{N})$ & 91.8 & 119 & 5.44 & $<0.001$ & \\
\hline NEL20 (MJ $/ \mathrm{kg}$ of DM) & 6.25 & 5.41 & 0.169 & $<0.001$ & 7.49 \\
\hline AAT20 $(\mathrm{g} / \mathrm{kg}$ of DM $)$ & 68.2 & 68.8 & 0.463 & 0.63 & 129 \\
\hline PBV20 $(\mathrm{g} / \mathrm{kg}$ of DM $)$ & 79.0 & 28.0 & 9.68 & $<0.001$ & 17.0 \\
\hline $\mathrm{FV}(\mathrm{FV} / \mathrm{kg}$ of $\mathrm{DM})$ & 0.472 & 0.572 & 0.0192 & $<0.001$ & 0.220 \\
\hline
\end{tabular}

${ }^{1} \mathrm{OMD}=$ organic matter digestibility; $\mathrm{sCP}=$ soluble crude protein; $\mathrm{CFat}=$ crude fat; $\mathrm{WSC}=$ water-soluble carbohydrates; NEL20 = standard feed value for $\mathrm{NE}_{\mathrm{L}}$ at $20 \mathrm{~kg}$ of DMI/d. For compound feed, NEL20 vas calculated according to Álvarez et al. (2021). AAT20 = standard feed value for amino acids absorbed in the small intestine at $20 \mathrm{~kg}$ of DMI $/ \mathrm{d} ;$ PBV20 = standard feed value for protein balance in the rumen at $20 \mathrm{~kg}$ of $\mathrm{DMI} / \mathrm{d} ; \mathrm{FV}=$ fill value of the feedstuff.

${ }^{2} \mathrm{HDS}=$ high-digestible silage; LDS $=$ low-digestible silage. Each silage included 4 pooled samples $(2$ per response period) out of every other day sampling. Days of silage conservation: HDS $277 \mathrm{~d}$ and LDS $256 \mathrm{~d}$ at the beginning of experiment.

${ }^{3}$ Concentrate sample consisted in 3 pooled samples out of weekly sampling. The concentrate comprised $30.5 \%$ barley, $16.2 \%$ soybean meal, $11.1 \%$ oat, $10 \%$ maize, $9.1 \% \%$ wheat, $6 \%$ sugar beet pellets, $5 \%$ molasses, $4 \%$ rapeseed cake, $3 \%$ beans, and $5.1 \%$ mineral and vitamin mix (fresh basis).

bales per group. The HDS cows were offered 3 mixed bales from the early-cut silage, one from each field, and LDS cows were offered 3 mixed bales from the latecut silage, again one from each field. Concentrate level was determined by optimization in NorFor Feed Ration Optimizer with the corresponding silage digestibility and information of individual milk yield, weight, and DIM recorded from PreP. In response period 2 (RP2), from April 5 to 25 (20 d duration), each group was further randomly divided into 3 subgroups; in this case, no diet optimization was performed. Instead, a group of 10 cows maintained the concentrate offer level from RP1 (standard), another group of 10 cows increased 2 $\mathrm{kg}$ of $\mathrm{DM} / \mathrm{d}$ from the standard concentrate level from RP1 (Plus2), and a third 10-cow group was offered 2 $\mathrm{kg}$ of $\mathrm{DM} / \mathrm{d}$ less concentrate than the standard level from RP1 (Minus2). This resulted in 6 subgroups for RP2: 3 from HDS with standard concentrate (HDSstandard), HDS with increased concentrate offer (HDS-Plus2), HDS with decreased concentrate offer
(HDS-Minus2), and 3 from LDS with standard concentrate (LDS-standard), LDS with increased concentrate offer (LDS-Plus2), and LDS with decreased concentrate offer (LDS-Minus2). As in RP1, silage mixing was performed for this period. For all periods, the offered concentrate was a commercial compound comprising $30.5 \%$ barley, $16.2 \%$ soybean meal, $11.1 \%$ oat, $10 \%$ maize, $9.1 \% \%$ wheat, $6 \%$ sugar beet pellets, $5 \%$ molasses, $4 \%$ rapeseed cake, $3 \%$ beans, and $5.1 \%$ mineral and vitamin mix (fresh basis). Table 1 shows the chemical composition of the concentrates.

\section{Animals, Housing, Feeding, and Management}

The 60 Norwegian red cows - 26 first lactation, 22 second lactation, and 12 older cows - were loosely housed with concrete floors and rubber mats with sawdust for the whole experiment. At the end of PreP, cows had the following averages $( \pm \mathrm{SD}): 599 \pm 56.7$ BW, $130 \pm 28.8$ DIM, $32.1 \pm 6.73 \mathrm{~kg}$ of ECM, and 21.6 
\pm 3.27 DMI. The silages were fed from 40 individual automatic feeders (BioControl AS) equipped with vertically moving gates, where electronic cow identification ensured each cow's access to the correct silage source. For PreP, the 40 bins were filled with the mixed silage. For RP1 and RP2, half of the bins were filled with LDS and the other half with HDS. Silage was fed into the feed bins once a day, between 0700 and $0800 \mathrm{~h}$. The concentrate mixture was fed in the milking robot, 3 concentrate feeders and 2 GreenFeed Emission Monitor Systems (GEM, C-Lock Technology Inc.). The concentrate feeders and the GreenFeed units were located central to the barn, accessible through a Smart Gate (DeLaval International). All units were equipped with a back-gate, allowing intake of concentrate without interference. The 60 cows used were introduced to the feeding and milking system in good time before the start of the experiment. Cows had access to water ad libitum, silage ad libitum, and the allowed concentrate level all day. The concentrate was distributed with 1 kg per day in the GreenFeed units, and the remaining part in the milking robot and any of the 3 concentrate feeders. Concentrate offering was restricted to a maximum of $4 \mathrm{~kg}$ per feeding and a time gap of $4 \mathrm{~h}$ between the 2 feedings, depending on total daily allocation. In RP2, changes in concentrate for the Plus2 and Minus2 groups were made by increasing and reducing the offer in the concentrate feeders, respectively.

\section{Experimental Measurements, Analysis, and Calculations}

Feed intake was recorded daily. Silage was recorded using the bin's weighing mechanism as the difference in weight between opening and closing the bin gate. Daily silage intake was the sum of all individual visits. Intake of concentrate was recorded by volume in the milking robot feeder, concentrate feeders, and GEM. None of these concentrate feeding systems measured leftovers; therefore, it was assumed that the amount fed was all eaten by the animal. Samples of silage were taken every second day and subsampled into samples every $2 \mathrm{wk}$ for analysis. Samples of concentrate were taken weekly and pooled into period samples (3 samples in total) for analysis. Dry matter content for silage was determined by drying at $60^{\circ} \mathrm{C}$ and adjusted for losses of volatiles, as described by Åkerlind et al. (2011). For concentrate, $\mathrm{DM}$ was determined by oven drying at $103^{\circ} \mathrm{C}$ for $24 \mathrm{~h}$. Samples for chemical analysis were ground using a cutter mill fitted with a $1.0-\mathrm{mm}$ screen. For concentrate, a proportion was also ground using a $0.5-\mathrm{mm}$ screen for starch analysis. Feed samples were analyzed for nitrogen, according to the Kjeldahl method using the Kjeltec 8400 automated distillation unit (Foss Analyti- cal), and $\mathrm{CP}$ was estimated as $\mathrm{N} \times 6.25$. Soluble $\mathrm{CP}$ (sCP) was determined according to NorFor by extracting samples in a borate-phosphate buffer. After centrifugation, the $\mathrm{sCP}$ in the supernatant was determined using the Kjeldahl method. Crude fat was determined by accelerated solvent extraction using a Dionex ASE 350 Accelerated Solvent Extractor (Thermo Scientific). Analyses for NDF, ADF, and ADL were performed using the Ankom ${ }^{200}$ Fiber Analyzer (Ankom Technology Corporation). The NDF (ash-corrected) was determined using the amylase-treated NDF method (Mertens et al., 2002). The ADF (ash-corrected) was determined by incubating the sample for $60 \mathrm{~min}$ with sulfuric acid and cetyl trimethylammonium bromide, and ADL (Ankom Technologies, 2017) was determined after ADF determination by incubating the samples in sulfuric acid for $3 \mathrm{~h}$ (Ankom Technologies, 2020). Starch was determined by first hydrolyzation with $\alpha$-amylase and amylo-glucosidase to glucose, which was finally determined spectrophotometrically by color reaction using RX Daytona + (Randox Laboratories Ltd.). Ash was determined by incineration at $550^{\circ} \mathrm{C}$ for $8 \mathrm{~h}$ (European Commission, 2009). Organic matter digestibility in vivo was predicted by near-infrared analysis at Eurofins Agro, calibrated to the rumen fluid in vitro method (Tilley and Terry, 1963). Calculation of standard feed values at $20 \mathrm{~kg}$ of $\mathrm{DM} / \mathrm{d}$ intake level was done according to NorFor (Åkerlind and Volden, 2011), giving $\mathrm{NE}_{\mathrm{L}}, \mathrm{AA}$ absorbed in the small intestine, and protein balance in the rumen. Fill value for silages and total diet $\mathrm{NE}_{\mathrm{L}}$ was also calculated according to NorFor (Volden, 2011a).

Daily milk yield (MY) was recorded in an automatic milking system (DeLaval International), where the yield was registered for each milking. At the end of each experimental period, milk samples were taken for each milking for a 48 -h period. Each milk sample was preserved using Bronopol tablets (2-bromo-2-nitropropane-1,3 diol, Broad Spectrum Microtabs II) and stored chilled $\left(4^{\circ} \mathrm{C}\right)$ until analyzed for fat, protein, and lactose using Fourier Transform Infrared (FTIR) spectroscopy (Bentley FTS/FCM or Combi 150, Bentley Instruments Inc.) at the Tine laboratory (Trondheim, Norway). The individual milk samples were linked to their respective yields and used to determine the weighted average milk composition over this 48-h period. Energy-corrected milk was then calculated from this chemical composition according to Sjaunja et al. (1990). Body weight was measured after each milking with an electronic scale situated at the milking robot exit.

Methane daily emissions were recorded with 2 GEM throughout the whole experiment. The GEM is a spot sampling method of eructated and exhaled gases and uses gas concentration and air flow to determine $\mathrm{CH}_{4}$ 
flux (Huhtanen et al., 2015). The span gas calibration of $\mathrm{CH}_{4}$ and $\mathrm{CO}_{2}$ was performed every fourth day and test recovery of $\mathrm{CO}_{2}$ was done every other week. Airflow rates and gas concentrations were measured continually so animal emissions could be calculated. In the barn, the GEM were placed next to each other and between the concentrate feeders and visited by animals voluntarily; thus, recording was reliant on animal visits. The total number of cows with voluntary continuous daily measurements of methane was 34 cows. For $\mathrm{RP} 1$, this represented 15 cows with recordings from the HDS group and 19 from the LDS. The number of cows with methane recordings per subtreatment in RP2 were as follows: 5, HDS-Plus2; 5, HDS-standard; 5, HDS-Minus2; 5, LDS-Plus2; 8, LDS-standard; and 7, LDS-Minus2. The other cows did not visit the unit voluntarily, or their visits were sporadic; therefore, access to the GEM was prohibited before the start of PreP. Animals had free access to the GEM, but a maximum of 5 visits with a minimum visit interval of $4 \mathrm{~h}$ was set. For every visit, 5 drops of concentrate every $25 \mathrm{~s}$ was offered, with each drop containing $40 \mathrm{~g}$ of the fed common concentrate fed. For a recording to be accepted as valid, at least $2 \mathrm{~min}$ of proximity to the sensor of the head position were set as criteria. Average $\mathrm{CH}_{4}$ daily values were calculated with recordings corresponding to the same day.

For all measurements, the last $10 \mathrm{~d}$ of each period were included as repeated measurements or used to calculate an average per cow to avoid potential carryover effects from the previous period.

\section{Statistical Analyses}

Silage Composition. As the objective of the study depended on achieving 2 different silage digestibilities, a statistical comparison was performed between the HDS and LDS by one-way ANOVA using the "aov" function from the "stats" package (R Core Team, 2019). Four samples per silage (2 samples per silage per response period) were included in the comparison, where silage was the main effect, and all nutritional components were evaluated as response variables. If significant, pairwise comparison by Tukey was performed using the "TukeyHSD" function, also from the stats package.

Response Periods 1 and 2. The experiment was a complete randomized block design, with parity as the block (primiparous vs. multiparous). All statistical analyses were performed in RStudio (RStudio Team, 2020). Randomization of the experimental unit for cow was done using the "block_ra" function from the "randomizr" package (Coppock, 2019). For RP1, the effect of silage digestibility and change in concentrate from
PreP on feed intake, milk yield, and $\mathrm{CH}_{4}$ were analyzed using linear mixed models with the "lme" function from the "nlme" package (Pinheiro et al., 2020) using RStudio software. The models evaluated MY, ECM, milk fat concentration, milk protein concentration, milk lactose concentration, fat yield, protein yield, lactose milk, silage DMI (DMIs), concentrate DMI (DMIc), DMI, weight, $\mathrm{CH}_{4}$, methane yield $\left(\mathrm{CH}_{4} / \mathrm{DMI}\right)$, and methane intensity $\left(\mathrm{CH}_{4} / \mathrm{ECM}\right)$. Silage digestibility (HDS or LDS) and change in concentrate ( $\mathrm{kg}$ of $\mathrm{DM} / \mathrm{d})$ and the silage digestibility $\times$ change in concentrate interactions were included as fixed effects. A covariate was included in the model to account for variation between cows, and it was nested within parity. The covariate used for the different dependent variables corresponded to the same evaluated variable but with values from before the start of the period, which corresponded to PreP for RP1 evaluation. Therefore, change in concentrate from PreP to RP1 was selected as an independent variable as opposed to DMIc. Cow was used as random variable. An autoregressive correlation structure of CAR(1) was applied to account for correlation among repeated measurements (daily measures) within cow. For treatment comparison were done using Tukey test procedure by the "ghlt" function from the "multicomp" package (Hothorn et al., 2008). The results were considered statistically significant at $P \leq 0.05$, and $P$-values $>0.05$ and $\leq 0.1$ were considered to indicate trends.

For RP2, models for the same dependent variables as RP1 were also analyzed with linear mixed models using the same statistical software and function as for RP1. Random variables, correlation structure, post hoc test, and significance level were also the same as RP1. Models included concentrate level as the categorical main fixed effect (standard, Plus2, and Minus2). As values for RP1 were included as covariates for this period, silage digestibility was not included as a main effect for RP2, as this was evaluated in RP1, and the effect of digestibility was thus included in the covariate. Silage digestibility was only included in the interaction term to evaluate the effect of the concentrate level on the different silage digestibilities. Substitution rate was calculated for RP2 only for the treatments where the concentrate offer was changed (Plus2 and Minus2). The SR was calculated for each individual cow as the change in DMIs per kilogram change in DMIc.

\section{RESULTS}

\section{Silage Composition}

Table 1 presents the chemical composition of the grass silages and concentrates. The HDS showed higher 
DM content $(P=0.02)$, OMD $(P<0.001)$, concentrations of $\mathrm{CP}(P<0.001)$, sCP $(P<0.001)$, crude fat $(P=0.006)$, starch $(P<0.001)$, and WSC $(P<0.001)$ than LDS. Concentration of NDF $(P<0.001)$, ADF $(P$ $<0.001)$, and ADL $(P<0.001)$ were higher for LDS. Fermentation quality parameters such as lactic acid $(P$ $=0.02)$, acetic acid $(P=0.02)$, and ammonium-N $(P$ $<0.001)$ concentrations were higher for LDS, whereas HDS showed higher $\mathrm{pH}(P=0.02)$ and formic acid concentration $(P=0.01)$. Energy standard feed value and protein balance in the rumen were higher for HDS $(P<0.001)$, whereas no difference in AA absorbed in the small intestine was found $(P=0.63)$. Fill value was higher for LDS $(P<0.001)$.

\section{Response Period 1}

Of the 60 cows included in the experiment, 6 were taken out during RP2 and excluded from the whole experiment. From these excluded cows, 3 were excluded due to stealing HDS and 3 due to low MY not related to treatments. This resulted in 27 cows for the HDS and 27 cows for the LDS, respectively. Table 2 shows the results for intake and yield for RP1.

Intake. Total DMI was, on average, $3.0 \mathrm{~kg}$ of DM/d higher for cows in the HDS than those in the LDS $(P<$ 0.001). Also, DMI increased $0.53 \mathrm{~kg}$ of $\mathrm{DM} / \mathrm{d}$ with each increase in kilograms of $\mathrm{DM} / \mathrm{d}$ of concentrate offer $(P$
$<0.001)$, regardless of silage digestibility treatments, as no interaction was found between silage digestibility and change in concentrate offer $(P=0.76)$. Higher DMI for the HDS group could be explained by DMIs, which was, on average, $3.8 \mathrm{~kg}$ of DM/d higher for the HDS group than for the LDS group $(P<0.001)$. No interaction was found for DMIs between silage digestibility and concentrate offer $(P=0.13)$. Regardless of silage digestibility, DMIs were reduced by $0.26 \mathrm{~kg}$ of $\mathrm{DM} / \mathrm{d}$ with an increase in each kilogram of DM/d of concentrate offer $(P<0.001)$. Concentrate intake was lower for $\operatorname{HDS}(P=0.04)$ and increased for both silage digestibility treatments by $0.82 \mathrm{~kg}$ of $\mathrm{DM} / \mathrm{d}$ when concentrate offer was increased by $1 \mathrm{~kg}$ of $\mathrm{DM} / \mathrm{d}(P$ $<0.001$ ). Residual concentrate, defined as the concentrate allowed but not fed out to the animals, showed no difference between silage digestibility $(P=0.51)$ or concentrate offer change $(P=0.19)$.

Milk Production and Composition. Milk yield was, on average, $3.0 \mathrm{~kg}$ higher for the HDS than the LDS treatment $(P=0.001)$ and increased linearly by $0.49 \mathrm{~kg}$ of milk per $\mathrm{kg}$ increased offer of concentrate $(P$ $=0.01)$, regardless of silage digestibility, as no interaction was found $(P=0.90)$. Similar response was found for ECM, with, on average, a $3.5 \mathrm{~kg}$ higher yield for the HDS than the LDS treatment. Irrespective of silage digestibility, ECM showed a linear increase in $0.66 \mathrm{~kg}$ per $\mathrm{kg}$ of DM of concentrate offer increase, as no inter-

Table 2. Estimated least squares means of the effect of silage digestibility treatment (HDS vs. LDS) and change in concentrate offer (kg of $\mathrm{DM} / \mathrm{d}$ ) on milk yield, milk components, and intake in response period 1

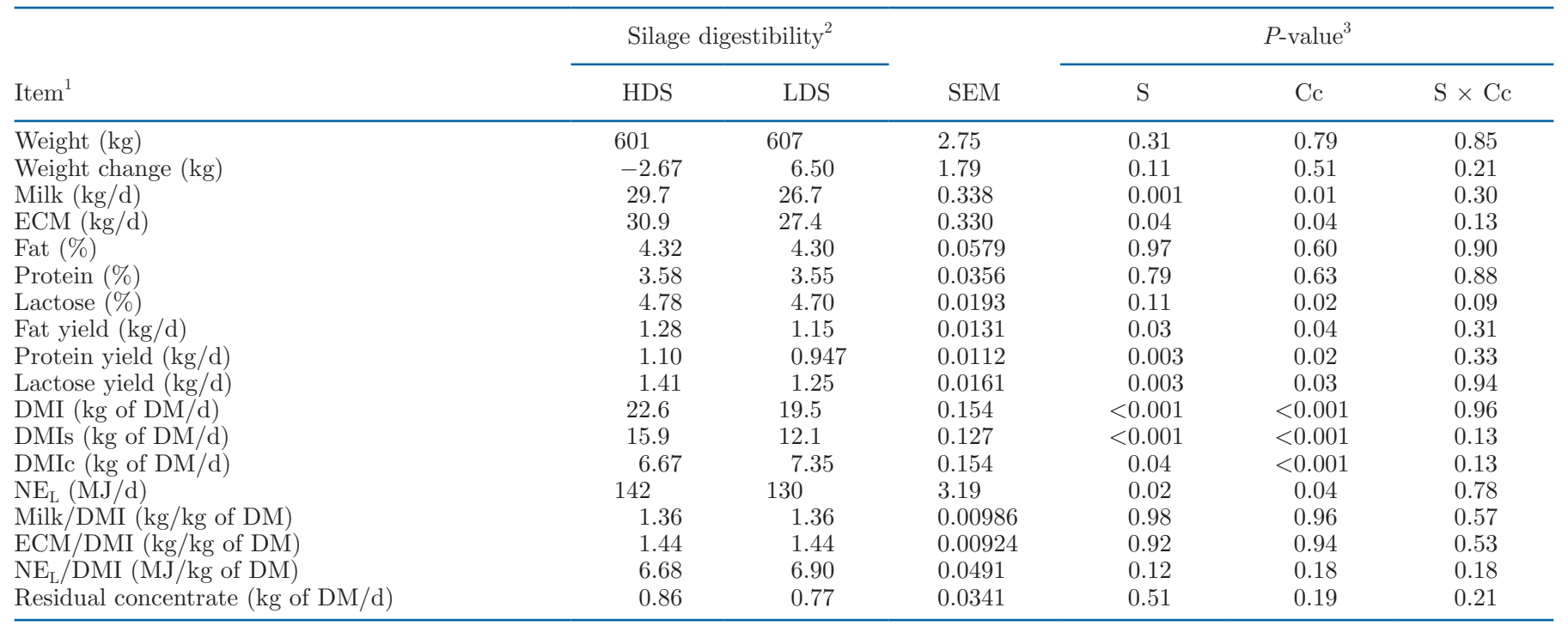

${ }^{1}$ DMIc = dry matter intake of the concentrate; DMIs = dry matter intake of the silage; residual concentrate: offered but not fed out concentrate (DM offer minus DMIc).

${ }^{2} \mathrm{HDS}=$ high-digestible silage; LDS $=$ low-digestible silage.

${ }^{3} \mathrm{~S}=$ silage digestibility effect; $\mathrm{Cc}=$ concentrate change effect; $\mathrm{S} \times \mathrm{C}=$ interaction between silage digestibility and concentrate change effect. 
action was found $(P=0.13)$. Silage digestibility did not affect fat and protein concentrations $(P=0.97$ and $P$ $=0.79)$, likewise change in concentrate offer $(P=0.60$ and $P=0.63)$. For both silage digestibility treatments, the lactose concentration increased with an increased concentrate offer $(P=0.02)$. Fat, protein, and lactose yield were highest for the HDS treatment $(P=0.03$ for fat yield and $P=0.003$ for protein and lactose yield) and were affected by concentrate offer $(P<0.05)$, although no interaction was detected for any of these parameters $(P>0.10)$. Weight and weight change was not affected by silage digestibility $(P=0.31$ and $P=$ 0.11 , respectively) or change in concentrate offer $(P=$ 0.79 and $P=0.21$, respectively).

Methane Emissions. Table 3 shows the results for methane emissions for RP1. Out of the 54 cows $(27$ per group), 34 cows had a continuous voluntary daily visit to the GEM and resulted in $64 \%$ of the cows with methane recordings. Methane production per cow $(\mathrm{g} / \mathrm{d})$ were not affected by silage digestibility $(P=0.70)$ or a change in concentrate offer $(P=0.84)$. Methane intensity was not affected by silage or concentrate offer $(P$ $=0.21$ and $P=0.87$, respectively), and no interaction was found between silage digestibility and concentrate offer $(P=0.63)$. Methane yield was, on average, $2.6 \mathrm{~g} /$ $\mathrm{kg}$ of DMI higher for LDS $(P=0.002)$ and significantly decreased by $0.43 \mathrm{~g} / \mathrm{kg}$ of DMI with an increased offer of concentrate $(P=0.02)$, but no interaction between silage digestibility and concentrate offer was found $(P$ $=0.89$ ). Average values of methane intensity for individual cows for period RP1 (Figure 1) were regressed against DMI and showed a decrease with increased DMI $(P<0.001)$ with no effect of silage type $(P>0.13)$.

\section{Response Period 2}

All cows included in RP1 continued in the experiment for RP2, where they were subdivided into the 3

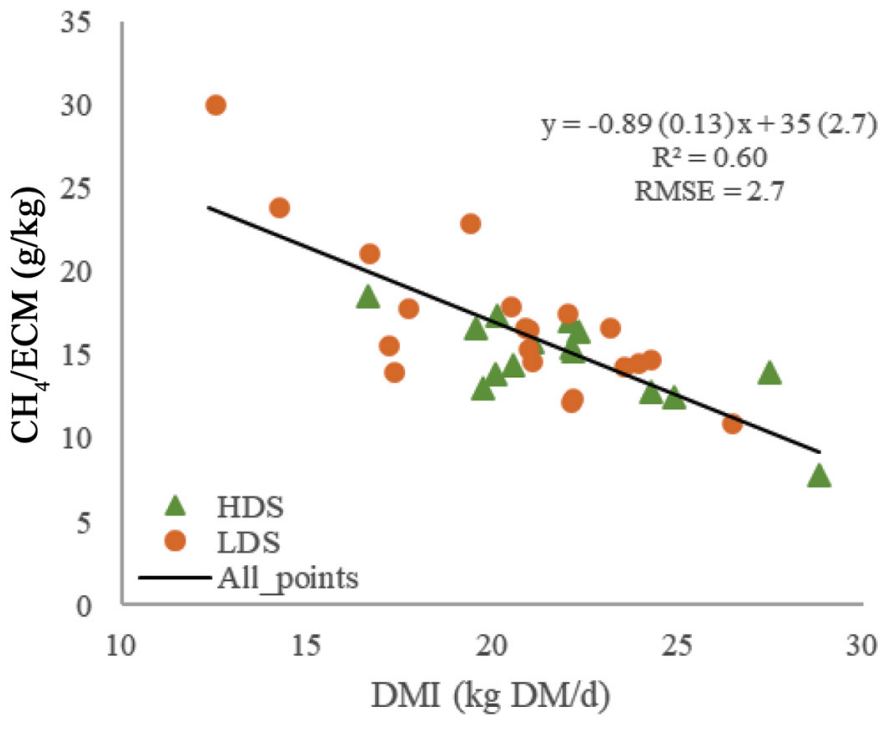

Figure 1. Effect of total DMI on methane intensity ( $\mathrm{g} / \mathrm{kg}$ of ECM) for individual cows for response period 1 . HDS = high-digestible silage; LDS = low-digestible silage; all_points = regression including both silage digestibility groups. $\mathrm{CH}_{4} / \mathrm{ECM}=$ methane intensity $(\mathrm{g} /$ $\mathrm{kg})$. RMSE $=$ root mean square error.

concentrate level subgroups. Due to the cows excluded from the experiment, the number of cows per subgroup was as follows: 10, HDS-Plus2; 10, HDS-standard; 7, HDS-Minus2; 10, LDS-Plus2; 9, LDS-standard; 8, LDSMinus2. Uneven distribution of cows in the subgroups was because the removal of cows was done during this period and excluded from the whole experiment. Table 4 shows the results for RP2.

Intake. Table 4 shows both the least squares means and raw means for silage, concentrate, and total DMI. Due to the use of a covariate, estimated least squares means of intakes appear numerically similar between concentrate levels for both silage digestibility, whereas raw means show actual intakes. Concentrate intake was significantly affected by concentrate offer $(P<0.001)$

Table 3. Estimated least squares means of the effect of silage digestibility treatment and concentrate offer on methane production $(\mathrm{g} / \mathrm{d})$, intensity $(\mathrm{g} / \mathrm{kg}$ of $\mathrm{ECM})$, and yield $(\mathrm{g} / \mathrm{kg}$ of $\mathrm{DM})$ per cow in response period 1

\begin{tabular}{|c|c|c|c|c|c|c|}
\hline \multirow[b]{2}{*}{ Item $^{1}$} & \multicolumn{2}{|c|}{ Silage digestibility $^{2}$} & \multirow[b]{2}{*}{ SEM } & \multicolumn{3}{|c|}{$P$-value ${ }^{3}$} \\
\hline & HDS & LDS & & S & $\mathrm{Cc}$ & $\mathrm{S} \times \mathrm{Cc}$ \\
\hline $\mathrm{n}$ & 15 & 19 & & & & \\
\hline $\mathrm{CH}_{4}(\mathrm{~g} / \mathrm{d})$ & 457 & 459 & 6.72 & 0.70 & 0.84 & 0.84 \\
\hline $\mathrm{CH}_{4} / \mathrm{ECM}(\mathrm{g} / \mathrm{kg})$ & 15.2 & 16.3 & 0.440 & 0.21 & 0.87 & 0.63 \\
\hline $\mathrm{CH}_{4} / \mathrm{DMI}(\mathrm{g} / \mathrm{kg}$ of $\mathrm{DM})$ & 20.3 & 22.9 & 0.314 & 0.002 & 0.02 & 0.89 \\
\hline
\end{tabular}

${ }_{\mathrm{n}} \mathrm{n}=$ number of cows with methane measurements; $\mathrm{CH}_{4} / \mathrm{ECM}=$ methane intensity; $\mathrm{CH}_{4} / \mathrm{DMI}=$ methane yield.

${ }^{2} \mathrm{HDS}=$ high-digestible silage LDS $=$ low-digestible silage.

${ }^{3} \mathrm{~S}=$ silage digestibility effect; $\mathrm{Cc}=$ concentrate change effect; $\mathrm{S} \times \mathrm{Cc}=$ interaction between silage digestibility and concentrate change effect. 
Table 4. Estimated least squares means of the effect of concentrate level treatment (Plus2 vs. standard vs. Minus2) and silage digestibility (HDS vs. LDS on milk yield, milk components, and intake) in response period 2

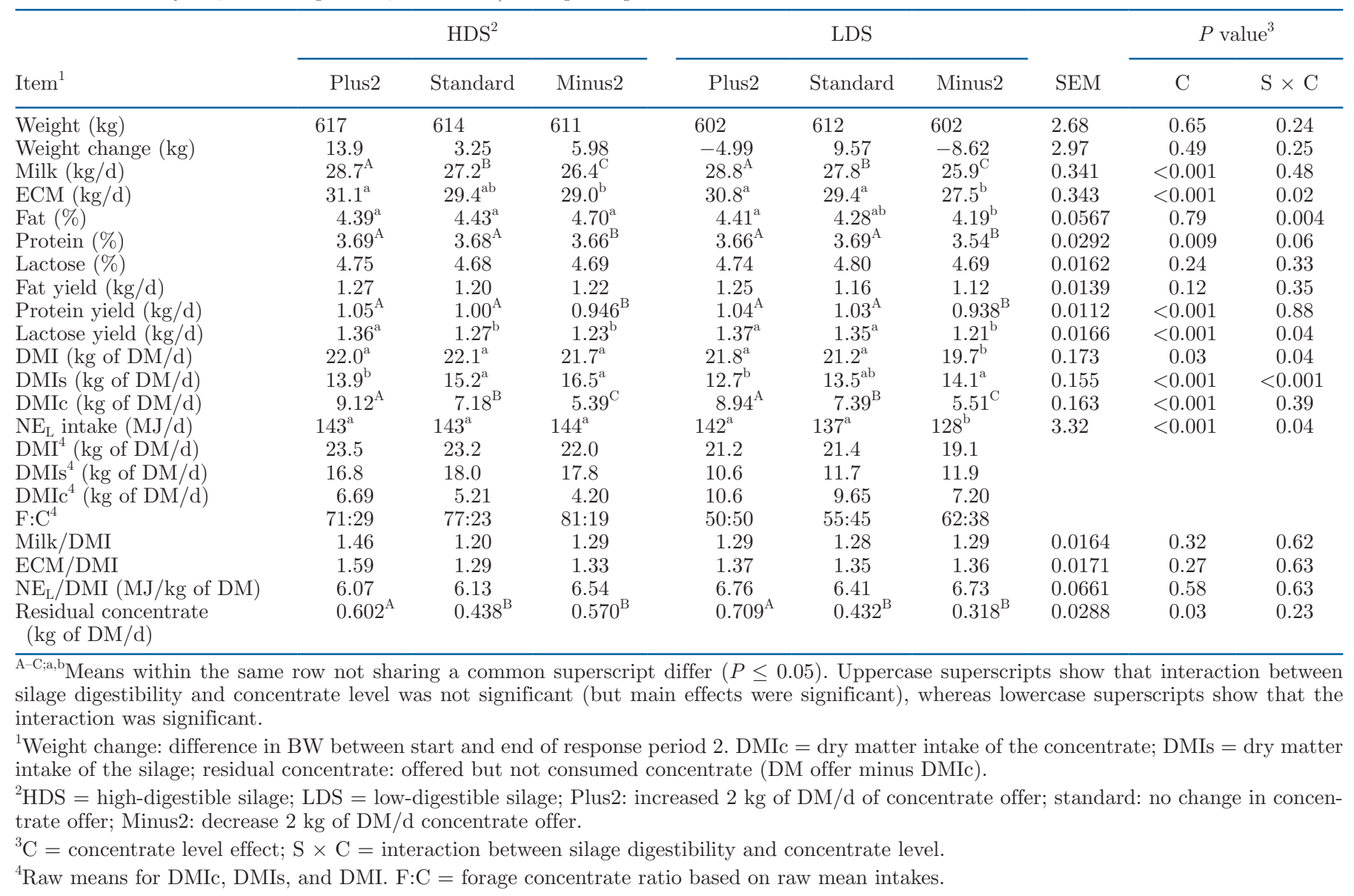

with Plus2 showing the highest intake and Minus2 the lowest for both silages, and no interaction was found $(P$ $=0.39)$. Residual concentrate showed higher values for Plus2 than the other concentrate levels $(P=0.03)$, regardless of silage digestibility $(P=0.23)$. Silage intake was affected by concentrate level $(P<0.001)$, depending on the silage digestibility $(P<0.001)$. For LDS, increasing the concentrate level did not affect DMIs, but DMIs decreased by $1.3 \mathrm{~kg}$ of DM/d for HDS. For both silages, there was a significant difference for DMIs between the highest and lowest concentrate levels (Minus2 vs. Plus2). For HDS-Plus2, DMIs were $2.6 \mathrm{~kg}$ lower than for Minus2. For LDS, Plus2 showed $1.4 \mathrm{~kg}$ lower DMIs than for Minus2. Total DMI showed a significant effect of concentrate level $(P=0.03)$ with an interaction with silage digestibility $(P=0.04)$. Although no difference was detected between concentrate levels for HDS, LDS showed lower DMI when the concentrate offer was Minus2. The $\mathrm{NE}_{\mathrm{L}}$ intake showed similar results to DMI, with an interaction between silage digestibility and concentrate level $(P=0.04)$. The $\mathrm{NE}_{\mathrm{L}}$ showed no differences between concentrate offer treatments for HDS, whereas for lower LDS, $\mathrm{NE}_{\mathrm{L}}$ intake was shown for LDS-Minus2 treatment.

Substitution Rate. Substitution rate was calculated only for cows allocated in the treatments where the concentrate offer was changed (HDS-Plus2, LDS-Plus2, HDS-Minus2, and LDS-Minus2). Average SR was 0.59. The HDS treatment showed a higher average SR (0.78) than LDS (0.42). Figure 2 shows the SR for each individual cow according to changes in DMIc. The HDS treatment showed a higher increase in DMIs with the reduction of concentrate intake and a higher reduction when concentrate increased, showing a variable SR. For LDS, SR was constant, showing a similar reduction or increase in DMIs when DMIc increased or decreased, respectively.

Milk Production and Composition. Concentrate level affected MY $(P<0.001)$, with higher MY for increasing concentrate level (Plus2) and decreased when concentrate offer was reduced (Minus2) with no interaction between silage digestibility and concentrate 


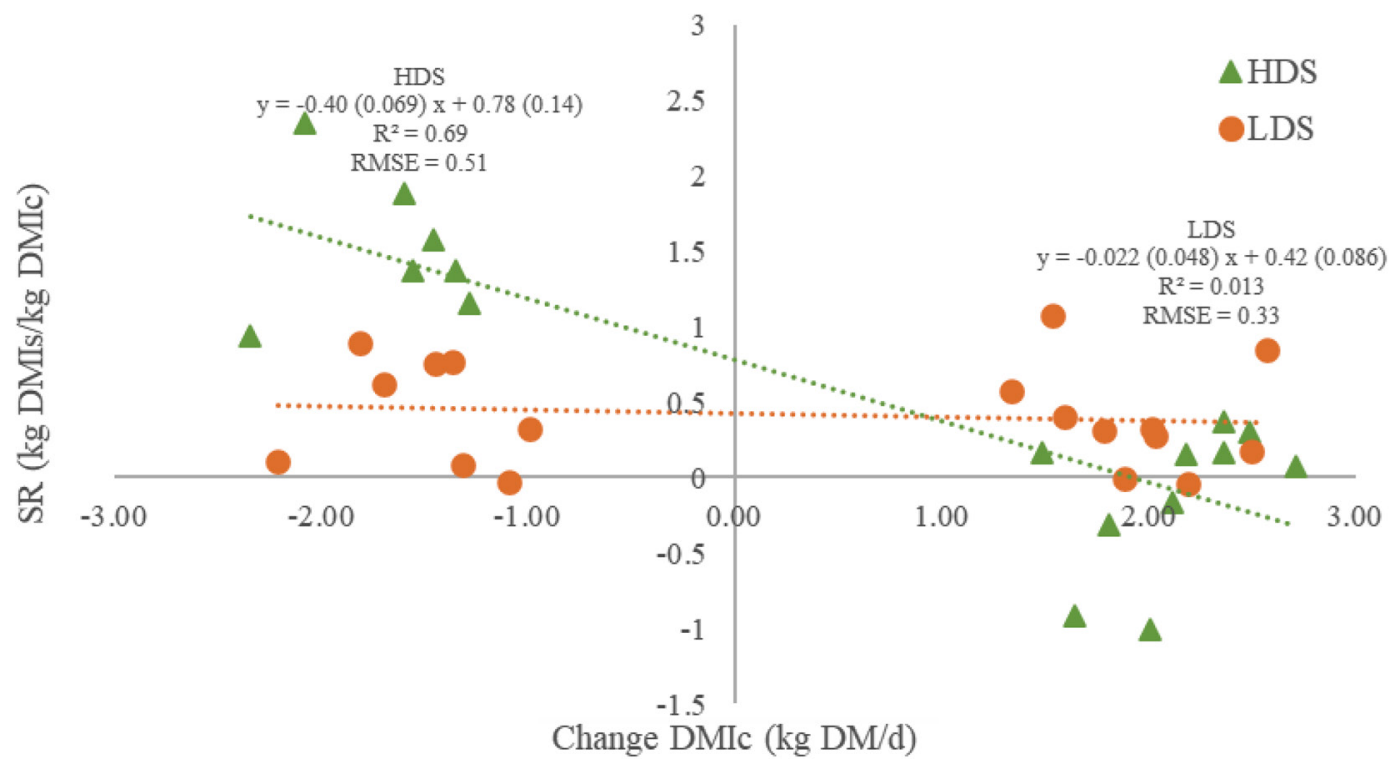

Figure 2. Substitution rate (change in silage intake with changes in concentrate intake) for individual cows for 2 silage digestibilities. SR $=$ substitution rate $=($ DMIs response period $2-$ DMIs response period 1$) /($ DMIc response period $2-$ DMIc response period 1$)$, where DMIs $=$ silage intake and DMIc = concentrate intake. HDS = high-digestible silage; LDS = low-digestible silage. Change DMIc: change of concentrate dry matter intake $=$ DMIc response period $2-$ DMIc response period 1 . RMSE $=$ root mean square error.

offer level $(P=0.48)$. However, ECM showed an interaction with concentrate offer $(P=0.02)$; HDS showed no differences for Minus2 compared with standard, but LDS showed a lower yield for Minus2 treatment. Milk fat concentration was not different within HDS, although higher numerical concentrations were found for the Minus2 treatment. For LDS, Minus2 showed a lower milk fat concentration than Plus2 $(P=0.004)$. Milk protein concentration was reduced for both silages for the Minus2 treatment $(P=0.009)$.

Figure 3 shows a comparison of the ECM response between the predicted values according to Álvarez et al. (2020) and observed results of the present study. Predicted results were calculated for the specific OMD of the silages in this study and the raw means of DMIc. For the HDS, the predicted response of ECM by the model to increasing DMIc from Minus2 to standard was $0.89 \mathrm{~kg}$ of ECM, whereas the observed was an increase in $0.4 \mathrm{~kg}$ of ECM. The predicted response to an increase in DMIc from standard to Plus2 was $1.1 \mathrm{~kg}$ of ECM, whereas the observed was $1.7 \mathrm{~kg}$ of ECM. Predicted total response for increasing DMIc from HDS-Minus2 to HDS-Plus2 was $2.1 \mathrm{~kg}$ of ECM, whereas the observed was $1.8 \mathrm{~kg}$ of ECM. For the LDS, the predicted and observed responses of ECM to concentrate intake shift from Minus2 to standard was $1.9 \mathrm{~kg}$ of ECM. Predicted response from standard to Plus2 was $0.5 \mathrm{~kg}$ of ECM, whereas the observed was $1.4 \mathrm{~kg}$ of ECM. Predicted total response from Minus2 to Plus2 for LDS was smaller than the observed ( $2.3 \mathrm{vs} .3 .3 \mathrm{~kg}$ of ECM, respectively).
Weight and BW change were not affected by concentrate intake $(P=0.65$ and 0.46 , respectively). However, numerically higher weight change was recorded for HDS-Plus2 compared with HDS-standard and HDSMinus2.

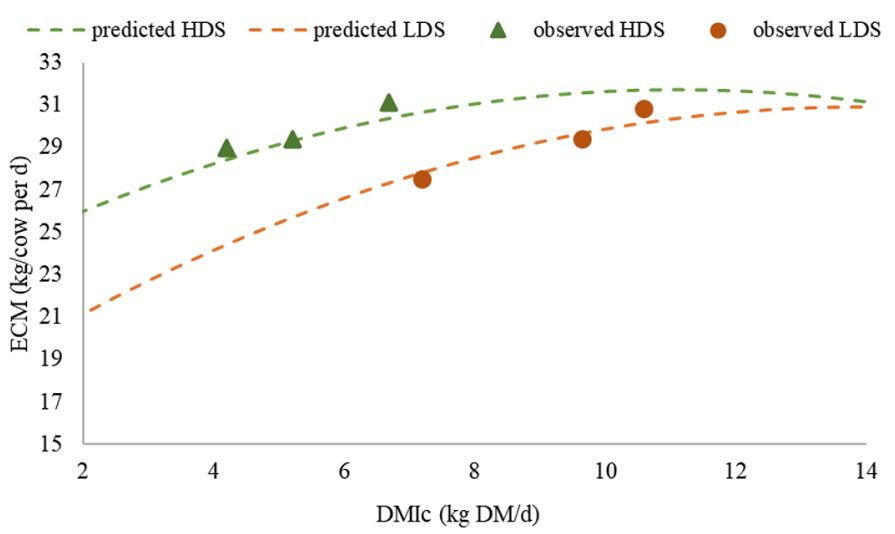

Figure 3. Relationship between concentrate intake (DMIc) and predicted ECM (kg/d) by Álvarez et al. (2020) at the 2 silage organic matter digestibility (OMDs) levels observed in the study (high vs. low digestible silages) compared with observed ECM of the study. Model for prediction of ECM: ECM $(\mathrm{kg} /$ cow per d $)=-16.1+4.21$ DMIc $(\mathrm{kg}$ of DM/d) - 0.0692 DMIc ( $\mathrm{kg}$ of DM/d) $)^{2}+0.498$ OMDs (\%) - 0.0339 DMIc $(\mathrm{kg}$ of $\mathrm{DM} / \mathrm{d}) \times$ OMDs $(\%)$. Predicted HDS: predicted ECM according to Álvarez et al. (2020) for OMDs $=78.9 \%$. Predicted LDS: predicted ECM according to Álvarez et al. (2020) for OMDs $=67.6 \%$. Observed HDS: observed ECM in this study for the high-digestible silage for 3 concentrate levels. Observed LDS: observed ECM in this study for the low-digestible silage for 3 concentrate levels. 
Methane Emissions. Table 5 presents the results for $\mathrm{CH}_{4}$ emissions. Methane production were affected by concentrate level $(P=0.02)$, which was higher for Plus2 than for Minus2, regardless of silage digestibility. However, methane intensity and yield were not affected by the concentrate level $(P>0.10)$.

Figures 4 present the regression of methane intensity against DMI for the average period values of individual cows, respectively. Methane intensity also showed a decrease in $1.23 \mathrm{~L} / \mathrm{kg}$ of DMI increase $(P<0.001)$, with no effect of silage digestibility $(P=0.60)$.

\section{DISCUSSION}

\section{Silage Characteristics}

Our results agree with the well-known fact that plants mature as harvest date is postponed, increasing cell walls and lignin fractions (Buxton, 1996). In grass silage, this results in increased NDF and ADF proportion, whereas the proportion of $\mathrm{CP}$ and digestibility decreases. Some studies have shown similar results (e.g., Rinne et al., 1999; Kuoppala et al., 2008; Alstrup et al., 2016). However, silage quality varies greatly depending on year, botanical composition, silage making, and so on (Buxton, 1996). Moreover, as latitude and altitude also play a part in the harvest date effect, the magnitude of the effect of harvest date should be compared within location or at least region. Studies from the same location as ours agree with the observed trends in the effect of silage composition but differences in magnitude. For example, Dønnem et al. (2011) showed a higher daily decrease in OMD for later harvest $(0.83$ vs. 0.57 percentage points) but a lower daily decrease in CP (2.43 vs. $3.55 \mathrm{~g} / \mathrm{kg}$ of DM) and a higher increase in NDF content (7.19 vs. $6.45 \mathrm{~g} / \mathrm{kg}$ of DM per day). Randby et al. (2012) showed a similar decrease in CP

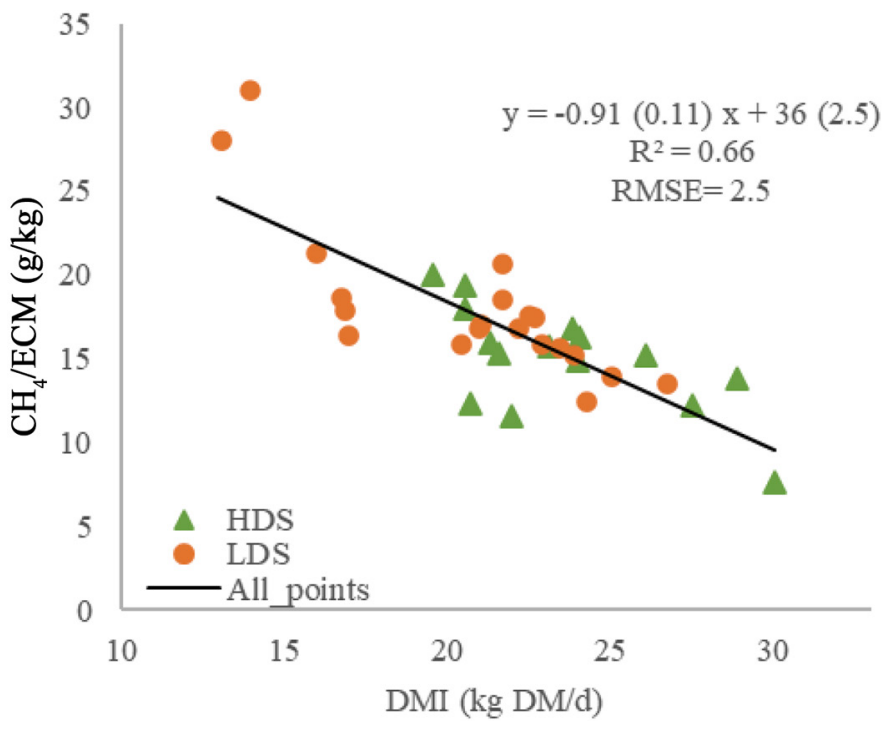

Figure 4. Effect of DMI on methane intensity $\left(\mathrm{CH}_{4} / \mathrm{ECM}\right)$ for individual cows in response period $2 . \mathrm{HDS}=$ high-digestible silage; LDS $=$ low-digestible silage; all_points $=$ regression including both silage digestibility groups. RMSE = root mean square error.

content per day $(3.31 \mathrm{~g} / \mathrm{kg}$ of DM) but a higher OMD decrease rate (0.71 percentage points/d) and NDF increase $(7.75 \mathrm{~g} / \mathrm{kg}$ of DM). Harvest date effect on silage composition due to differences in maturity was shown, in the present study again, to be an important management practice to improve silage composition (Harrison et al., 1994; Buxton, 1996).

\section{Effect of Silage Digestibility}

The use of a covariate allowed for accounting for variation between cows, making it easier to detect the significance of the evaluated variables (Lee et al., 2019) and increase statistical power (Jacobs et al., 2013; Ka-

Table 5. Estimated least squares means of the effect of silage digestibility treatment and concentrate offer on methane production (g/d), intensity $(\mathrm{g} / \mathrm{kg}$ of $\mathrm{ECM})$, and yield $(\mathrm{g} / \mathrm{kg}$ of $\mathrm{DM})$ per cow in response period 2

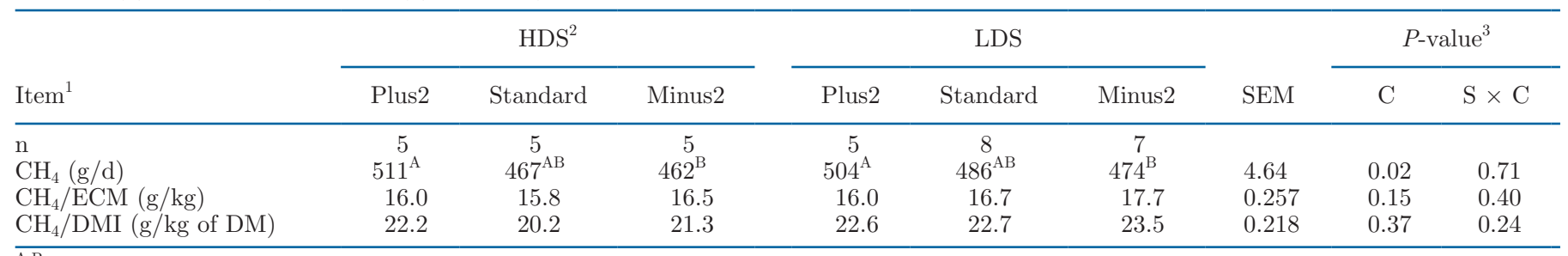

\footnotetext{
${ }_{\mathrm{A}, \mathrm{B}}$ Means within the same row not sharing a common superscript differ $(P \leq 0.05)$. Uppercase superscripts show that the interaction between silage digestibility and concentrate level was not significant (but main effects were significant).

${ }^{1} \mathrm{n}$ : number of cows with methane measurements. $\mathrm{CH}_{4} / \mathrm{ECM}=$ methane intensity; $\mathrm{CH}_{4} / \mathrm{DMI}=$ methane yield.

${ }^{2} \mathrm{HDS}=$ high-digestible silage; LDS = low-digestible silage; Plus2: increased $2 \mathrm{~kg}$ of DM/d of concentrate offer; standard: no change in concentrate offer; Minus2: decrease $2 \mathrm{~kg}$ of DM/d concentrate offer.

${ }^{3} \mathrm{C}=$ concentrate level effect; $\mathrm{S} \times \mathrm{C}=$ interaction between silage digestibility and concentrate level effect.
} 


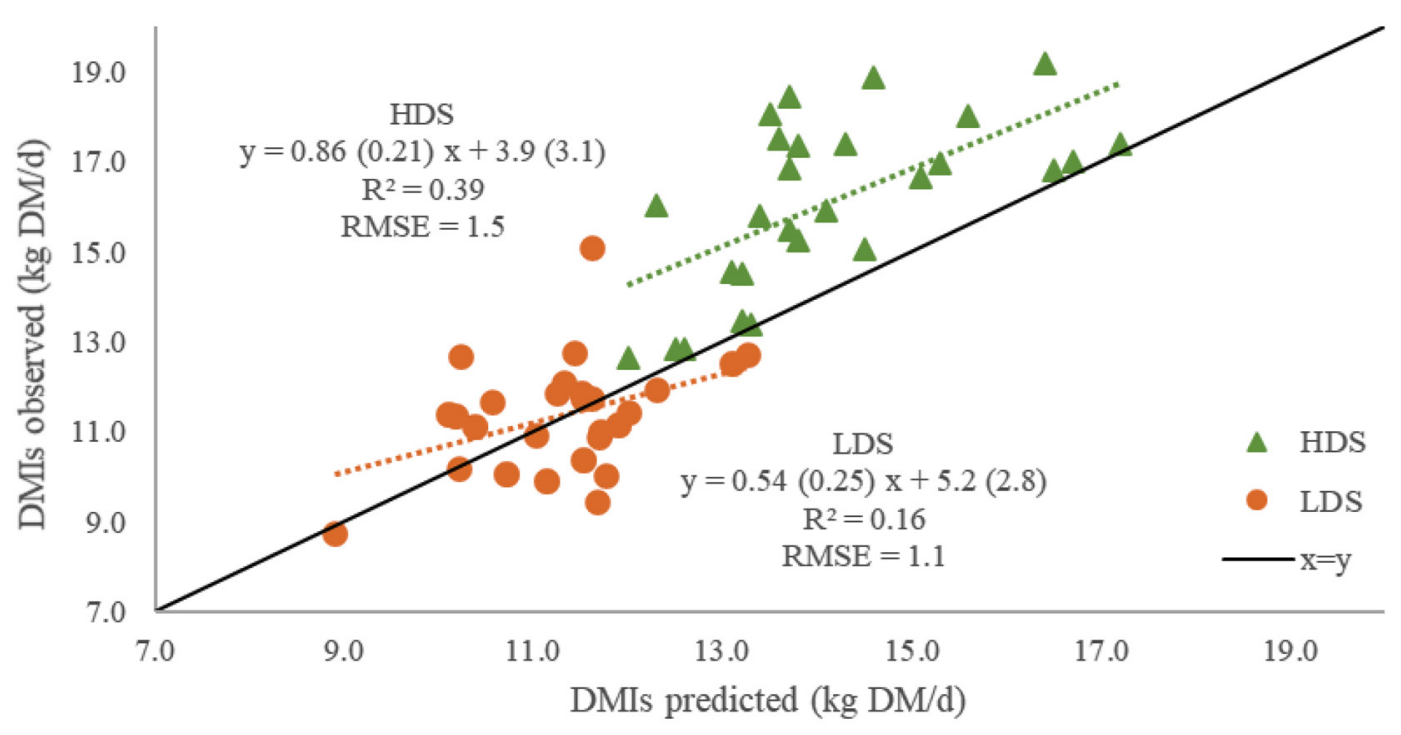

Figure 5. Dry matter intake of the silage (DMIs) predicted by the Nordic Feed Evaluation System (NorFor) optimization for individual cows against observed DMIs in response period 1. HDS = high-digestible silage; LDS = low-digestible silage. DMIs observed: dry matter intake of silage recorded in the study. DMIs predicted: dry matter intake of silage predicted by NorFor from optimization for RP1. RMSE $=$ root mean square error.

han et al., 2014; Thompson et al., 2015). Moreover, by including covariate as a baseline measurement (values from before the experiment) allowed us to compare how the study variables changed to the introduced treatments. In our study, the experimental design allowed the use of a covariate from the previous period as a baseline measurement. For evaluating the effect of silage digestibility in RP1, values from the previous period (PreP) were included as covariate. This allowed the comparison of cows that were previously subjected to the common silage as baseline.

The cows' diets were individually optimized according to the yield and silage assigned. As anticipated, rations optimized by NorFor attributed less concentrate offer for the HDS than for the LDS treatment due to the difference in energy concentration between the 2 silages. A separate feeding strategy allowed us to evaluate the effect of concentrate and silage intake on milk production. Concentrate intake was higher for the LDS and was a direct effect of a higher concentrate offer, as the residual concentrate was not different between silage digestibility treatments. Dry matter intake was expected to be similar between treatments, as initial yield was alike, and diets were optimized by NorFor to maintain these yields. Higher DMI for HDS treatment was due to higher than predicted values of DMIs for HDS by NorFor (Figure 5). Jensen et al. (2015) showed that the NorFor intake model overpredicts DMI at high intake levels, which contrasts our results on which NorFor underpredicted at high intake levels. In addition, this underprediction was not shown for high intakes in PreP when an intermediate mixed silage (50\% LDS and $50 \%$ HDS) was fed. Therefore, this systematic underprediction could relate to silage quality rather than the intake level and should be further studied. Higher DMI probably explains the higher MY and ECM yields for the HDS treatment, as feed efficiency (milk/DMI, $\mathrm{ECM} / \mathrm{DMI}$, and $\mathrm{NE}_{\mathrm{L}} / \mathrm{kg}$ of $\mathrm{DM}$ ) did not differ between silage treatments. Higher yield with increased intake supports the fact that total intake is the most important factor determining animal production (Waldo, 1986; Allen, 2000). Regardless of intake underprediction, the results from RP1 confirmed our hypothesis that high milk yields can be produced with low concentrate offers if high-digestible silages are fed. Results of this study are based on short-term periods and could show differences if study periods were longer should be interpreted accordingly.

\section{Concentrate Level and Interaction with Silage Digestibility}

The effect of the concentrate level was evaluated in RP2, separate from the silage digestibility evaluation in RP1. The goal in this period was to evaluate responses to changes in concentrate supply. This was achieved by optimizing the concentrate level for all cows according to their individual yield and the 2 silages in the previous period (RP1). Therefore, to evaluate the effect of concentrate level in RP2, the results from RP1 were used as a covariate. The values from RP1 included the effect of silage digestibility as it was evaluated in 
that period, so inclusion of RP1 values as a covariate masked the effect of silage digestibility. Therefore, only a comparison between concentrate levels within each silage digestibility treatment was performed. Thereby, the effect of silage digestibility was included only in the interaction term to detect different trends of concentrate levels between the silage groups.

Concentrate levels similarly affected DMI and $\mathrm{NE}_{\mathrm{L}}$ intakes, with no differences between concentrate levels in the HDS but lower DMI and $\mathrm{NE}_{\mathrm{L}}$ for Minus2 in the LDS. Low-digestible silages could not compensate for the reduction of concentrate offer with higher silage intake, probably because maximum intake potential was already reached in the optimized concentrate level. Although silage intake for concentrate levels in HDS did not significantly differ, there was a numerical increase in $1.3 \mathrm{~kg}$ of DMIs/d with a decrease in the $2 \mathrm{~kg}$ of DM/d concentrate offer, whereas the increase in LDS was $0.6 \mathrm{~kg}$ of DM/d. Average SR of $0.59 \mathrm{~kg}$ of $\mathrm{DM}$ in this study exceeded the 0.53 found by Álvarez et al. (2020) and 0.47 reported by Huhtanen et al. (2008). Differences in the SR values between studies could be attributed to the type of silage, level, and type of concentrate alongside cow characteristics used in the different studies. Huhtanen et al. (2008) and Álvarez et al. (2020) showed no differences in SR between silage digestibility, whereas, in this study, higher SR was detected for HDS. The differences in SR between silages revealed in this study agree with Thomas (1987), Faverdin et al. (1991), and Jensen et al. (2016).

The differences shown in ECM between concentrate levels within silages were similar with the differences shown for DMI, which is supported by the similar ECM/ DMI shown between concentrate level treatments. When concentrate was reduced, HDS maintained DMI and ECM production, whereas LDS showed a reduction of DMI and ECM for LDS-Minus2 treatment. The lower MY of cows fed HDS with low concentrate intake was compensated for by the numerically higher milk fat concentration, probably due to higher silage intake, showing no differences in fat yield. Reducing concentrate for the LDS showed a lower milk fat concentration and was not expected. However, Sutton (1989) showed high variability in milk fat concentration due to several factors affecting it. Thus, other factors could have affected this result. The decrease in milk protein concentration with deceased concentrate shown for both silages agrees with Rinne et al. (1999), Kuoppala et al. (2008), and Alstrup et al. (2016), reflecting the negative relationship between NDF intake and milk protein concentration (Sutton, 1989). However, differences in milk protein yield were not enough to be reflected in different ECM between concentrate treatments, as
ECM for HDS was similar between HDS-standard and HDS-Minus2. This was not expected, as Álvarez et al. (2020) predicted responses of ECM for those concentrate levels. For the LDS, reduced ECM with reduced concentrate intake corresponded to the meta-analysis (Álvarez et al., 2020). This lower MY could not be compensated for by milk fat concentration; therefore, a lower ECM was recorded for this treatment.

Results of this study confirm our hypothesis, that lower intake levels of concentrate are needed to maintain high yields with high-digestible silages. Results show that it is possible to maintain high yields with a high proportion of silage in the diet by feeding HDS ( $81 \%$ for HDS-Minus2). However, this is not possible by feeding silages with lower digestibility. In our study, increasing the silage proportion from 55 to $62 \%$ of an LDS in the diet could not maintain the same yields. Although the results cannot be statistically compared between silages, numerically higher ECM was achieved with HDS at similar concentrate levels (Figure 3, LDSMinus2 vs. HDS-Plus2). From another perspective, numerically similar ECM yields to HDS can only be achieved by feeding LDS with high concentrate intakes. Moreover, the marginal responses of the ECM shown in this study agree with our hypothesis based on Álvarez et al. (2020) by showing lower marginal responses to concentrate increases for high-digestible silages. Several explanations for the lower ECM responses with increased concentrate intake for high-digestible silages can be found in the literature. Lower ECM responses could be driven by lower intake with increased concentrate intake due to higher SR for high-digestible silages, as shown in this study (Huhtanen et al., 2002; Kuoppala et al., 2008). Other explanations are the shift of nutrient allocation toward body reserves (Randby et al., 2012), but only numerical differences of increased weight for increased concentrate intake in HDS were found in this study. Longer study period may show clearer differences than in this study. Finally, a more accentuated negative effect of concentrate intake on NDF digestibility in high-digestible silages was reported as an explanation by Rinne et al. (1999) and Alstrup et al. (2016). Results of milk responses in the current study emphasize the benefit of feeding high-digestible silages with low concentrate levels, but the advantage of high-digestible silages dilutes at higher supplies of concentrate (Ferris et al., 2001).

\section{Methane Production}

Usually, $\mathrm{CH}_{4}$ production increases with an increased total intake (Moe and Tyrrell, 1979; Nielsen et al., 2013; Warner et al., 2017; Niu et al., 2018). Thus, 
similar methane production for the 2 silage treatments was not expected because DMI was highest for HDS treatment. However, the higher NDF content and lower digestibility of late mature silages were shown to favor acetate production (Johnson and Johnson, 1995) and increase methane production (Moe and Tyrrell, 1979). This could have counterbalanced the lower DMI of LDS, resulting in similar total methane emissions. Similar methane production but higher intake for high-digestible silages was also shown by Brask et al. (2013). Brask et al. (2013) showed lower methane yield for high-digestible silages due to higher intake, in agreement with our study. The importance of intake was also reflected in the lack of differences found for methane yield and intensity at the same total intake level (Figures 3 and 4).

Methane production increased with an increased concentrate offer, regardless of silage digestibility. This differs from the results shown by many, although studies are also contradictory. Some studies have shown decreased methane production (Ferris et al., 1999; Aguerre et al., 2011), whereas others have revealed no differences (Patel et al., 2011; Jiao et al., 2014). However, differences in total methane production were not translated to methane yield and intensity. The lack of difference between concentrate levels for methane yield and intensity was probably because the differences in concentrate offer were minor (plus or minus $2 \mathrm{~kg}$ of $\mathrm{DM} / \mathrm{d}$ ) and masked by SR, resulting in similar DMI. The negative relationship between methane yield and DMI shown for both periods agrees with most studies that intake is one of the most important factors determining total methane production (Moe and Tyrrell, 1979; Nielsen et al., 2013; Warner et al., 2017; Niu et al., 2018). Moreover, a similar relationship between methane intensity and DMI was also expected due to the high relationship between milk yield and intake (Johnson and Johnson, 1995; Niu et al., 2018).

\section{CONCLUSIONS}

Our study evaluated the relationship between silage digestibility and concentrate supply level on intake, milk, and methane production. Unlike low-digestible silages, high yields can be maintained with low concentrate levels with HDS. This demonstrates the benefits of feeding high-digestible silages with low concentrate levels, which disappear if concentrate levels are increased. Our study also showed that methane production was not affected by feeding high-digestible silages with low concentrate levels and that methane yield and intensity depends more on total intake than on silage digestibility and concentrate level when silage is fed for ad libitum intake.

\section{ACKNOWLEDGMENTS}

The authors thank the staff at the Animal Production Experimental Center for help with silage production and assistance with animal care, and the laboratory staff at the Department of Animal and Aquacultural Sciences for sample preparation and chemical analysis. The authors also thank the Research Council of Norway (Oslo, Norway), NorFor (Aarhus, Denmark), Tine (Oslo, Norway), and NMBU (Ås, Norway) co-funding through the automatic milking system (AMS) project for financing this study. The authors have not stated any conflicts of interest.

\section{REFERENCES}

Abrahamse, P. A., B. Vlaeminck, S. Tamminga, and J. Dijkstra. 2008. The effect of silage and concentrate type on intake behavior, rumen function, and milk production in dairy cows in early and late lactation. J. Dairy Sci. 91:4778-4792. https://doi.org/10.3168/jds .2008-1350.

Aguerre, M. J., M. A. Wattiaux, J. M. Powell, G. A. Broderick, and C. Arndt. 2011. Effect of forage-to-concentrate ratio in dairy cow diets on emission of methane, carbon dioxide, and ammonia, lactation performance, and manure excretion. J. Dairy Sci. 94:30813093. https://doi.org/10.3168/jds.2010-4011.

Åkerlind, M., and H. Volden. 2011. Standard feed value. Pages $137-$ 139 in NorFor-The Nordic Feed Evaluation System. H. Volden, ed. Wageningen Academic Publishers.

Åkerlind, M., M. R. Weisbjerg, T. Eriksson, R. Tøgersen, P. Udén, B. L. Ólafsson, O. M. Harstad, and H. Volden. 2011. Feed analyses and digestion methods. Pages 41-54 in NorFor-The Nordic Feed Evaluation System. H. Volden, ed. Wageningen Academic Publishers.

Allen, M. S. 2000. Effects of diet on short-term regulation of feed intake by lactating dairy cattle. J. Dairy Sci. 83:1598-1624. https:// doi.org/10.3168/jds.S0022-0302(00)75030-2.

Alstrup, L., K. Søegaard, and M. R. Weisbjerg. 2016. Effects of maturity and harvest season of grass-clover silage and of forage-toconcentrate ratio on milk production of dairy cows. J. Dairy Sci. 99:328-340. https://doi.org/10.3168/jds.2015-9802.

Alstrup, L., M. R. Weisbjerg, L. Hymøller, M. K. Larsen, P. Lund, and M. O. Nielsen. 2014. Milk production response to varying protein supply is independent of forage digestibility in dairy cows. J. Dairy Sci. 97:4412-4422. https://doi.org/10.3168/jds.2013-7585.

Álvarez, C., N. I. Nielsen, M. R. Weisbjerg, H. Volden, and E. Prestlokken. 2021. A static model for estimating energy content of compound feeds in a dynamic feed evaluation system. J. Dairy Sci. 104:9362-9375. https://doi.org/10.3168/jds.2020-19816.

Álvarez, C., M. R. Weisbjerg, N. I. Nielsen, E. Prestløkken, and H. Volden. 2020. Effect of digestibility of silage and concentrate intake on milk yield: A metanalysis. Pages 179-181 in Proceedings of the 28th General Meeting of the European Grassland Federation: Meeting the Future Demands for Grassland Production. Wageningen Academic Publishers.

Ankom Technologies. 2017. Acid detergent fiber in feeds - Filter bag technique (for A200 and A200I). Accessed Sep. 20, 2020. https: //www.ankom.com/sites/default/files/document-files/Method_5 _ADF_A200.pdf.

Ankom Technologies. 2020. Method 8 - Determining acid detergent lignin in beakers. Accessed Sep. 20, 2020. https://www.ankom .com/sites/default/files/document-files/Method_8_Lignin_in _beakers_0.pdf.

Bernardes, T. F., J. L. P. Daniel, A. T. Adesogan, T. A. McAllister, P. Drouin, L. G. Nussio, P. Huhtanen, G. F. Tremblay, G. Bélanger, and Y. Cai. 2018. Silage review: Unique challenges of silages made 
in hot and cold regions. J. Dairy Sci. 101:4001-4019. https://doi .org/10.3168/jds.2017-13703.

Brask, M., P. Lund, A. L. F. Hellwing, M. Poulsen, and M. R. Weisbjerg. 2013. Enteric methane production, digestibility and rumen fermentation in dairy cows fed different forages with and without rapeseed fat supplementation. Anim. Feed Sci. Technol. 184:67-79. https://doi.org/10.1016/j.anifeedsci.2013.06.006.

Buxton, D. R. 1996. Quality-related characteristics of forages as influenced by plant environment and agronomic factors. Anim. Feed Sci. Technol. 59:37-49. https://doi.org/10.1016/0377-8401(95)00885-3.

Coppock, A. 2019. randomizr: Easy-to-use tools for common forms of random assignment and sampling. Accessed Feb. 15, 2020. https:/ /CRAN.R-project.org/package=randomizr.

Dønnem, I., Å. T. Randby, and M. Eknæs. 2011. Effect of grass silage harvesting time and level of concentrate supplementation on goat milk quality. Anim. Feed Sci. Technol. 163:118-129. https://doi .org/10.1016/j.anifeedsci.2010.10.013.

European Commission. 2009. Laying down the methods of sampling and analysis for the official control of feed. Official Journal of the European Union 54:1-130.

Faverdin, P., J. P. Dulphy, J. B. Coulon, R. Vérité, J. P. Garel, J. Rouel, and B. Marquis. 1991. Substitution of roughage by concentrates for dairy cows. Livest. Prod. Sci. 27:137-156. https://doi .org/10.1016/0301-6226(91)90092-5.

Ferris, C. P., F. J. Gordon, D. C. Patterson, D. J. Kilpatrick, C. S. Mayne, and M. A. McCoy. 2001. The response of dairy cows of high genetic merit to increasing proportion of concentrate in the diet with a high and medium feed value silage. J. Agric. Sci. 136:319-329. https://doi.org/10.1017/S002185960100870X.

Ferris, C. P., F. J. Gordon, D. C. Patterson, M. G. Porter, and T. Yan. 1999. The effect of genetic merit and concentrate proportion in the diet on nutrient utilization by lactating dairy cows. J. Agric. Sci. 132:483-490. https://doi.org/10.1017/S0021859699006553.

Harrison, J. H., R. Blauwiekel, and M. R. Stokes. 1994. Fermentation and utilization of grass silage. J. Dairy Sci. 77:3209-3235. https:// doi.org/10.3168/jds.S0022-0302(94)77264-7.

Hothorn, T., F. Bretz, and P. Westfall. 2008. Simultaneous inference in general parametric models. Biom. J. 50:346-363. https://doi.org/ 10.1002/bimj. 200810425 .

Huhtanen, P., E. H. Cabezas-Garcia, S. Utsumi, and S. Zimmerman. 2015. Comparison of methods to determine methane emissions from dairy cows in farm conditions. J. Dairy Sci. 98:3394-3409. https://doi.org/10.3168/jds.2014-9118.

Huhtanen, P., H. Khalili, J. I. Nousiainen, M. Rinne, S. Jaakkola, T. Heikkilä, and J. Nousiainen. 2002. Prediction of the relative intake potential of grass silage by dairy cows. Livest. Prod. Sci. 73:111130. https://doi.org/10.1016/S0301-6226(01)00279-2.

Huhtanen, P., M. Rinne, and J. Nousiainen. 2008. Evaluation of concentrate factors affecting silage intake of dairy cows: A development of the relative total diet intake index. Animal 2:942-953. https://doi.org/10.1017/S1751731108001924.

Jacobs, B. M., J. F. Patience, M. D. Lindemann, K. J. Stalder, and B. J. Kerr. 2013. The use of a covariate reduces experimental error in nutrient digestion studies in growing pigs. J. Anim. Sci. 91:804-810. https://doi.org/10.2527/jas.2011-4868.

Jensen, L. M., B. Markussen, N. I. Nielsen, E. Nadeau, M. R. Weisbjerg, and P. Nørgaard. 2016. Description and evaluation of a net energy intake model as a function of dietary chewing index. J. Dairy Sci. 99:8699-8715. https://doi.org/10.3168/jds.2015-10389.

Jensen, L. M., N. I. Nielsen, E. Nadeau, B. Markussen, and P. Nørgaard. 2015. Evaluation of five models predicting feed intake by dairy cows fed total mixed rations. Livest. Sci. 176:91-103. https: //doi.org/10.1016/j.livsci.2015.03.026.

Jiao, H. P., A. J. Dale, A. F. Carson, S. Murray, A. W. Gordon, and C. P. Ferris. 2014. Effect of concentrate feed level on methane emissions from grazing dairy cows. J. Dairy Sci. 97:7043-7053. https:/ /doi.org/10.3168/jds.2014-7979.

Johnson, K. A., and D. E. Johnson. 1995. Methane emissions from cattle. J. Anim. Sci. 73:2483-2492. https://doi.org/10.2527/1995 $.7382483 x$
Kahan, B. C., V. Jairath, C. J. Doré, and T. P. Morris. 2014. The risks and rewards of covariate adjustment in randomized trials: An assessment of 12 outcomes from 8 studies. Trials 15:139. https://doi .org/10.1186/1745-6215-15-139.

Kuoppala, K., M. Rinne, J. Nousiainen, and P. Huhtanen. 2008. The effect of cutting time of grass silage in primary growth and regrowth and the interactions between silage quality and concentrate level on milk production of dairy cows. Livest. Sci. 116:171-182. https://doi.org/10.1016/j.livsci.2007.10.002.

Lee, U., T. P. Garcia, R. J. Carroll, K. R. Gilbreath, and G. Wu. 2019. Analysis of repeated measures data in nutrition research. Front. Biosci. 24:1377-1389. https://doi.org/10.2741/4785.

Mahanna, B., and L. E. Chase. 2003. Practical applications and solutions to silage problems. Pages $855-895$ in Silage Science and Technology. Agronomy Monograph no. 42. Am. Soc. Agron. and Crop Sci. Soc. Am.

Mertens, D. R., M. Allen, J. Carmany, J. Clegg, A. Davidowicz, M. Drouches, K. Frank, D. Gambin, M. Garkie, B. Gildemeister, D. Jeffress, C. S. Jeon, D. Jones, D. Kaplan, G. N. Kim, S. Kobata, D. Main, X. Moua, B. Paul, and M. Wolf. 2002. Gravimetric determination of amylase-treated neutral detergent fiber in feeds with refluxing in beakers or crucibles: Collaborative study. J. AOAC Int. 85:1217-1240.

Moe, P. W., and H. F. Tyrrell. 1979. Methane production in dairy cows. J. Dairy Sci. 62:1583-1586. https://doi.org/10.3168/jds .S0022-0302(79)83465-7.

Nielsen, N. I., H. Volden, M. Åkerlind, M. Brask, A. L. F. Hellwing, T. Storlien, and J. Bertilsson. 2013. A prediction equation for enteric methane emission from dairy cows for use in NorFor. Acta Agric. Scand. A Anim. Sci. 63:126-130. https://doi.org/10.1080/ 09064702.2013 .851275 .

Niu, M., E. Kebreab, A. N. Hristov, J. Oh, C. Arndt, A. Bannink, A. R. Bayat, A. F. Brito, T. Boland, D. Casper, L. A. Crompton, J. Dijkstra, M. A. Eugène, P. C. Garnsworthy, M. N. Haque, A. L. F. Hellwing, P. Huhtanen, M. Kreuzer, B. Kuhla, P. Lund, J. Madsen, C. Martin, S. C. McClelland, M. McGee, P. J. Moate, S. Muetzel, C. Muñoz, P. O'Kiely, N. Peiren, C. K. Reynolds, A. Schwarm, K. J. Shingfield, T. M. Storlien, M. R. Weisbjerg, D. R. Yáñez-Ruiz, and Z. Yu. 2018. Prediction of enteric methane production, yield, and intensity in dairy cattle using an intercontinental database. Glob. Chang. Biol. 24:3368-3389. https://doi .org/10.1111/gcb.14094.

Patel, M., E. Wredle, G. Börjesson, R. Danielsson, A. D. Iwaasa, E. Spörndly, and J. Bertilsson. 2011. Enteric methane emissions from dairy cows fed different proportions of highly digestible grass silage. Acta Agric. Scand. A Anim. Sci. 61:128-136. https://doi.org/ 10.1080/09064702.2011.616216.

Pinheiro, J., D. Bates, S. DebRoy, D. Sarkar, and R Core Team. 2020. nlme: Linear and Nonlinear Mixed Effects Models. R package version 3.1-149, https://CRAN.R-project.org/package=nlme.

R Core Team. 2019. R: A Language and Environment for Statistical Computing. R Foundation for Statistical Computing.

Randby, Å. T., M. R. Weisbjerg, P. Nørgaard, and B. Heringstad. 2012. Early lactation feed intake and milk yield responses of dairy cows offered grass silages harvested at early maturity stages. J. Dairy Sci. 95:304-317. https://doi.org/10.3168/jds.2011-4454.

Rinne, M., S. Jaakkola, K. Kaustell, T. Heikkilä, and P. Huhtanen. 1999. Silages harvested at different stages of grass growth v. concentrate foods as energy and protein sources in milk production. Anim. Sci. 69:251-263. https://doi.org/10.1017/S1357729800051286.

RStudio Team. 2020. RStudio: Integrated Development for R. RStudio. PBC.

Sjaunja, L. O., L. Bævre, I. Junkkarainen, J. Pedersen, and J. Setälä. 1990. A Nordic proposition for an energy corrected milk (ECM) formula. Pages 156-192 in 27th Session of the International Committee for Recording the Productivity of Milk Animals. European Association for Animal Production.

Sutton, J. D. 1989. Altering milk composition by feeding. J. Dairy Sci. 72:2801-2814. https://doi.org/10.3168/jds.S0022-0302(89)79426 -1 . 
Thomas, C. 1987. Factors affecting substitution rates in dairy cows on silage based rations. Pages 205-218 in Recent Advances in Animal Nutrition. D. J. A. Cole, W. Haresign, and W. Henrichsmeyer, ed. Butterworth-Heinemann.

Thompson, D. D., H. F. Lingsma, W. N. Whiteley, G. D. Murray, and E. W. Steyerberg. 2015. Covariate adjustment had similar benefits in small and large randomized controlled trials. J. Clin. Epidemiol. 68:1068-1075. https://doi.org/10.1016/j.jclinepi.2014.11.001.

Tilley, J. M. A., and R. A. Terry. 1963. A two-stage technique for the in vitro digestion of forage crops. Grass Forage Sci. 18:104-111. https://doi.org/10.1111/j.1365-2494.1963.tb00335.x.

Volden, H. 2011a. Feed calculations in NorFor. Pages 55-58 in NorForThe Nordic Feed Evaluation System. H. Volden, ed. Wageningen Academics Publishers.

Volden, H. 2011b. The NorFor IT system, ration formulation and optimization. Pages 167-177 in NorFor-The Nordic Feed Evaluation System. H. Volden, ed. Wageningen Academics Publishers.

Waldo, D. R. 1986. Effect of forage quality on intake and forage-concentrate interactions. J. Dairy Sci. 69:617-631. https://doi.org/10 .3168/jds.S0022-0302(86)80446-5.
Warner, D., A. Bannink, B. Hatew, H. van Laar, and J. Dijkstra. 2017. Effects of grass silage quality and level of feed intake on enteric methane production in lactating dairy cows. J. Anim. Sci. 95:3687-2700. https://doi.org/10.2527/jas.2017.1459.

Weisbjerg, M. R., and M. Johansen. 2017. A note on the response in feed intake and milk yield on increased forage organic matter digestibility. Pages 77-80 in Proc. 8th Nordic Feed Science Conference. Swedish University of Agricultural Sciences.

\section{ORCIDS}

C. Álvarez () https://orcid.org/0000-0001-7300-6831

N. I. Nielsen $\odot$ https://orcid.org/0000-0002-2838-0047

M. R. Weisbjerg ํ https://orcid.org/0000-0002-6514-9186

H. Volden ( ) https://orcid.org/0000-0002-5790-2086

M. Eknæs @ https://orcid.org/0000-0002-9577-4986

E. Prestløkken ำ https://orcid.org/0000-0003-3151-6782 